\title{
Understanding Adaptation and Natural Selection: Common Misconceptions
}

\author{
Bülent Keskin ${ }^{1}$ \\ Kazım Karabekir Faculty of Education, Ataturk University, Turkey \\ Esra Özay Köse ${ }^{2}$ \\ Kazım Karabekir Faculty of Education, Ataturk University, Turkey
}

\begin{abstract}
Constituting a central and unifying base for all biological fields, theory of evolution is an interdisciplinary subject and plays an important role in understanding some basic concepts of biology. The main purpose of this research is to identify biology pre-service teachers' misconceptions about adaptation and natural selection. For this purpose, research was conducted mixed methods research design that collects, analyzes, and mixes both quantitative and qualitative methods in a single study on 117 biology preservice teachers studying at 2th, 3th, 4th and 5th classes of Ataturk University Kazım Karabekir Education Faculty. Too many misconceptions about mechanism and purpose of adaptation and natural selection held by preservice teachers were determined through the qualitative and the quantitative data that were gained by using a two-tier diagnostic questionnaire that has 8 questions. Appropriate suggestions were made with the obtained results.
\end{abstract}

Submitted

13 April 2015

Revised

31 July 2015

Accepted

24 August 2015

Keywords:

Natural selection,

adaptation,

evolution,

misconceptions,

biology pre-service

teachers.

\section{Suggested Citation:}

Keskin, B., Köse, E. Ö. (2015). Understanding adaptation and natural selection: Common misconceptions. International Journal of Academic Research in Education, 1(2), 53-63. DOI: 10.17985/ijare.53146

\footnotetext{
${ }^{1}$ Atatürk University, kesbul@yahoo.com

${ }^{2}$ Corresponding author, Atatürk University esraozay@atauni.edu.tr
} 


\section{INTRODUCTION}

Concept teaching is the most significant phenomenon that requires due consideration in learning processes. If each concept carries an individual- or subject-specific distinct meaning, this may create a difference between the said and perceived, and also lead to a set of successive learning-teaching issues even up to conceptual misunderstandings. By gaining an understanding of the concepts for a particular field, relations between such concepts create a basis for new topics to be learned or taught. Therefore, wrong or incomplete teaching of a concept would trigger the subsequent relations, so this would lead to knock-on conceptual defects or misconceptions (Atasayar, 2008).

Misconception can be defined as a set of information not consistent with scientific facts acquired by students before or during the educational period (Atılboz, 2004). Misconceptions occurring in the minds of students prevent building of healthy ties with new concepts and significantly impair the realization of the meaningful learning process. In true and permanent teaching of knowledge, it is crucial to eliminate existing misconceptions and know about misconceptions in advance in favor of avoiding new misconceptions (Atılboz, 2004).

Students need to understand the content of natural and applied sciences. This is the only way of interpreting their own natural world and developing essential explanations for any phenomena they encounter. Helping to eliminate the misconceptions of students is directly correlated to streamlining their process of understanding the natural world they are a part of this process (Yağbasan and Gülçiçek, 2003).

When students first attend the formal science classes, they carry with them intuitions, prejudices and life experiences that are usually considered inconsistent. Such a combination induces various challenges in teaching the concepts during science classes (Yağbasan and Gülçiçek, 2003).

Topics of biology have an enriched potential for concepts (Selvi and Yağbasan, 2004). Biotechnology, cloning, global warming, recombinant DNA technology, antibiotic awareness and many other represent the most actively researched and socially followed topics of biology. And evolution constitutes a connective basis for all of the foregoing fields of biology (Grace, 2011). Evolution that can be regarded as central to biology is an interdisciplinary subject and plays a key role in understanding the basic subjects of biology including the structure of cell, cell division, inheritance, reproduction and so on (Banet and Ayuso, 2003; van Dijk, 2009; van Dijk and Kattman, 2009). Theory of evolution forms the basis of biology, and nothing in biology makes sense except in the light of evolution (Dobzhansky, 1973). Similarly, Gould (1982) likens a biology education not supported by the theory of evolution to chemistry without periodic table. Many researchers argue that it is not possible to understand modern biology without an understanding of evolution (Bishop and Anderson, 1990; Kose, 2010).

Biological evolution is the root cause of the diversity of life and its common origin, and it is the natural selection that makes it true. Biological evolution occurs through natural selection that induces a change in the frequency of alleles in the gene pool. This is also a very slow process.

Natural selection is one of the key reasons underlying transformations in living beings. Natural selection covers the organisms capable of getting suited to the environment. Changes in living things cannot efficiently be understood without the knowledge of adaptation and natural selection.

Several researches reveal that teachers, pre-service teachers and students have myriad of misconceptions in the study of biology, one of which is biological evolution (Baker and Piburn, 1997; Bergman, 1979; Blackwell, Powell and Dukes, 2003; Dagher and BouJaoude, 2005; Köse, 2010; Woods and Sharmann, 2001). It is obvious that there are problems in teaching the theory of evolution in Turkey. 
A study published in the journal Science reveals United States and Turkey as the two foremost countries where the theory of evolution is least welcomed (Miller, Scott and Okamoto, 2006).

Miller, Scott and Okamoto (2006) argue that the probable cause underlying the low rate of adoption of the theory of evolution by people is that people do not understand the concepts of biology in a broad sense. Understanding the theory of evolution from a scientific standpoint is very complex and multifaceted (Gould, 2002; Miller, 1999), so it is not surprising to see misconceptions in individuals failing to develop a good knowledge of theory of evolution (Miller, 1999).

Researchers attribute the difficulty experienced by teachers and students in understanding the theory of evolution to the misconceptions they carry and their information background (Gregory, 2009; Meir, Perry, Herron and Kingsolver, 2007). People usually tend to create reasons associated with their previous knowledge and experience when they cannot understand (Moore, 2002). And this urges the individual to fill the gaps in the theory of evolution with incorrect information that prevents full understanding of the theory. Therefore, it is necessary to maintain the focus of our people in understanding the science, and avoid misconceptions to ensure that individuals who are prospective researchers of the future are not adversely influenced. Identification of misconceptions in students on adaptation and natural selection through this study will help to eliminate these misconceptions and build a better understanding of the scientific theory and evolution.

\section{Purpose of the study}

The main purpose of this research, since it is naturally the responsibility of the biology teachers to effectively teach the theory of evolution in the class, is to identify misconceptions in biology pre-service teachers about adaptation and natural selection.

\section{METHOD}

\section{Design}

Research that was made to identify biology pre-service teachers' misconceptions about adaptation and natural selection, is an embedded design of mixed methods research design that collects, analyzes, and mixes both quantitative and qualitative methods in a single study. The purpose of the embedded design is to collect quantitative and qualitative data simultaneously or sequentially, but to have one form of data play a supportive role to the other form of data (Creswell, 2008). Some of the benefits of mixed methods designs are summarized and the shortcomings and challenges inherent in quantizing qualitative data in mixed methods research are delineated. Mixed methods designs can provide pragmatic advantages when exploring complex research questions. The qualitative data provide a deep understanding of survey responses, and statistical analysis can provide detailed assessment of pat terns of responses. However, the analytic process of combining qualitative and survey data by quantizing qualitative data can be time consuming and expensive and thus may lead researchers working under tight budgetary or time constraints to reduce sample sizes or limit the time spent interviewing. Ultimately, these designs seem most appropriate for research that does not require either extensive, deep analysis of qualitative data or multivariate analysis of quantitative data (Driscoll et al.,2007).

\section{Study groups}

The sample of research for misconceptions about adaptation and natural selection consists of 117 biology pre-service teachers (22 in second year, 30 in third year and 32 in fourth year and 33 in fifth year and 77 
female, 40 male) studying in Atatürk University Kazim Karabekir Education Faculty. Biology students study evolution in their all years in college.

\section{Data Collection}

The data collection tool used in this research created by researcher himself considering misconceptions located in the literature (Fahrenwald, 1999; Gregory, 2009; Köse, 2010; Pazza, Penteado and Kavako, 2010; Rutledge and Warden, 1999; Understanding Evolution, 2013; Varela, 2009; Yates, 2011). At the beginning a questionnaire that has 9 items was created considering common misconceptions addressed in the literature. 2 professors, 1 associate professor and 1 assistant professor all in biology reviewed the items in order to validate the questionnaire. Due to their comments 1 item removed from the questionnaire and 1 item was corrected. Misconceptions about adaptation and natural selection questionnaire is consists of 8 false-true items (Table 1). Cronbach's alpha coefficient of the questionnaire was found to be 0.83 . In a two-tier diagnostic questionnaire, the first tier of the items consists of a content question, while the second tier elicits a reasoning response. The purpose of the second tier arranged in an open-ended structure is to measure the reasoning ability of students better and to be able to determine whether they have alternative misconceptions another than previously determined (Mann and Treagust, 1998; Voska and Heikkinen, 2000).

Table 1. Misconceptions about adaptation and natural selection questionnaire

\begin{tabular}{|c|c|c|c|}
\hline \multirow{2}{*}{$\begin{array}{l}\text { Item } \\
\text { Number }\end{array}$} & Items & True & Misconception \\
\hline & & & \\
\hline 1 & Natural selection only involves organisms trying to adapt. & & $\mathrm{X}$ \\
\hline 2 & Natural selection gives organisms what they need to survive. & & $\mathrm{X}$ \\
\hline 3 & Natural selection doesn't always choose the best for organisms & $\mathrm{X}$ & \\
\hline 4 & $\begin{array}{l}\text { The fittest organisms in a population are those that are strongest, } \\
\text { healthiest, and/or largest. }\end{array}$ & & $x$ \\
\hline 5 & $\begin{array}{l}\text { Natural selection is about survival of the very fittest individuals in a } \\
\text { population. }\end{array}$ & & $\mathrm{x}$ \\
\hline 6 & $\begin{array}{l}\text { Natural selection doesn't produce organisms perfectly suited to their } \\
\text { environments. }\end{array}$ & $x$ & \\
\hline 7 & All traits of organisms are not adaptations. & $\mathrm{X}$ & \\
\hline 8 & Adaptation is a result of natural selection & $\mathrm{X}$ & \\
\hline
\end{tabular}

\section{Data Analysis}

The frequency and percent distributions used for the first tier of the misconceptions about adaptation and natural selection questionnaire while descriptive analysis of qualitative data analysis techniques were used at the second tier of the questionnaire.

\section{RESULTS}

The frequency and percent distribution results of the first tier of the misconceptions about adaptation and natural selection questionnaire are shown in Table 2. 
Table 2. Results of the first tier of the misconceptions about adaptation and natural selection questionnaire

\begin{tabular}{crrrrrr}
\hline \multirow{2}{*}{ Items } & \multicolumn{2}{c}{ True } & \multicolumn{3}{c}{ Misconception } & \multicolumn{2}{c}{ Blank } \\
\cline { 2 - 7 } & \multicolumn{1}{c}{$\mathrm{f}$} & $\%$ & $\mathrm{f}$ & $\%$ & $\mathrm{f}$ & $\%$ \\
\hline 1 & 78 & 66.67 & 34 & 29.06 & 5 & 4.27 \\
2 & 84 & 71.79 & 28 & 23.93 & 5 & 4.27 \\
3 & 69 & 58.97 & 40 & 34.19 & 8 & 6.84 \\
4 & 71 & 60.68 & 44 & 37.61 & 2 & 1.71 \\
5 & 104 & 88.89 & 8 & 6.84 & 5 & 4.27 \\
6 & 36 & 30.77 & 74 & 63.25 & 7 & 5.98 \\
7 & 91 & 77.78 & 24 & 20.51 & 2 & 1.71 \\
8 & 102 & 87.18 & 9 & 7.69 & 6 & 5.13 \\
\hline $\mathrm{n}=117$ & & & & & &
\end{tabular}

When Table 2 is analyzed nearly 80\% of biology pre-service teachers provided wrong answers to 1 of 8 questions (5th question). Nearly 70\% of them provided wrong answers to 1 of 8 questions (2th question). Nearly $60 \%$ of them provided wrong answers to 3 of 8 questions (1th, 4th, and 6 th questions). So, more than half of biology pre-service teachers provided wrong answers to 5 questions. Less than $50 \%$ of biology pre-service teachers ticked up wrong answers to the remaining 3 questions. Nearly $85 \%$ of them answered correctly to 1 of 8 questions (8th question).

The answers given to the second tier of the misconceptions about adaptation and natural selection questionnaire are read one by one and obtained misconceptions are listed below at Table 3 .

Table 3. Misconceptions about adaptation and natural selection

\begin{tabular}{ll}
\hline \multicolumn{1}{c}{ Misconceptions } & Frequency \\
\hline Natural selection is seen in living organisms who want to adapt to life & 55 students \\
Natural selection always choose the best for organisms & 49 students \\
According to the theory of evolution organisms that adapt are the strongest and & 41 students \\
healthiest & 33 students \\
The purpose of natural selection is adaptation of organisms & 14 students \\
Natural selection caters what organisms need & 12 students \\
Natural selection has to provide the necessary things that is essential for the survival of & 12 students \\
organisms in environmental conditions & 11 students \\
If natural selection doesn't choose the best for organisms than they can no longer survive & \\
All traits of organisms are adaptations because we have to adapt to the environment we & 10 students \\
live & 7 students \\
Because of giving essential things to the organisms to survive it is named natural selection & 7 students \\
Organisms carry out the necessary adaptations to live & 4 students \\
Organisms prepare all their traits according to the environment they live & \\
Natural selection is often realized as positive &
\end{tabular}




\begin{tabular}{ll}
\hline Natural selection doesn't affect the organisms whose adaptation ability is strong & 2 students \\
Natural selection occurs to make life more convenient & 2 students \\
Organisms adapt to the environment due to the need for the variation or modification & 1 students \\
Organisms who adapt undergo natural selection & 1 students
\end{tabular}

When Table 3 is analyzed most common misconceptions can be seen. Nearly half of the students have the misconception that natural selection is seen in living organisms who want to adapt to life. And another 49 of 117 students think that natural selection always choose the best for organisms. 41 of 117 students think that according to the theory of evolution organisms that adapt are the strongest and healthiest and 33 of 117 students think that the purpose of natural selection is adaptation of organisms. The other misconceptions are less common than this four.

\section{DISCUSSION}

Since it is naturally the responsibility of the biology teacher to effectively teach the theory of evolution in the class, this study aims to identify misconceptions in biology pre-service teachers about adaptation and natural selection. The results reveal that, in the questionnaire applied to identify misconceptions in biology pre-service teachers about adaptation and natural selection, the teachers ticked up too many wrong answers and that they carry many misconceptions as reflected by the supporting arguments accompanying their answers.

$66.7 \%$ of the students provided wrong answers to the first question (Table 2). As commonly revealed by the supporting arguments provided by the students, they wrongly believe that an organism deliberately suits to the environment through transformation (Table 3). But this is not the case for adaptation. Natural selection increases the frequency of certain genotypes of available variations, thus allowing the organism to suit to the environment (Hasenekoğlu, 2002). Natural selection enables the organisms to get suited to the environment they live necessarily without a desire, effort and experimentation (Understanding Evolution, 2013). The environment in which the organism lives defines the predominant aspect of the adaptive changes. The organism's desire to suit to a particular aspect has no relevance (Gregory, 2009).

71.79\% of the students provided wrong answers to the second question (Table 2). According to the supporting arguments provided by the students, majority of them wrongly believe that natural selection is underpinned at the organism's need (Table 3). Indeed, natural selection is not bound to the organism's need. In fact, natural selection has no prudence and sense of what organisms need (Gregory, 2009; Understanding Evolution, 2013).

34.19\% of the students provided wrong answers to the third question (Table 2). According to the supporting arguments provided by the students, they commonly have the wrong belief that natural selection generally strives to select the best organism in the environment (Table 3). Natural selection has no such prudence. Natural selection only selects individuals within a population capable of surviving and passing on this capability to subsequent generations (Hasenekoğlu, 2002; Understanding Evolution, 2013).

$60.68 \%$ of the students provided wrong answers to the fourth question (Table 2). According to the supporting arguments provided by the students, majority of them wrongly answer that the strongest 
organisms survive (Table 3). The underlying reason may be the common misjudgment "the strong survives and the weak is eliminated". Evolutionary fitness of an organism is its ability to transfer its genes to the next generation rather than its health or strength. Evolution has no relevance with length, speed or size (Understanding Evolution, 2013).

88.89\% of the students provided wrong answers to the fifth question (Table 2). According to the supporting arguments provided by the students, majority of them wrongly believe that natural selection has an intrinsic duty to select the strongest organism (Table 3). Despite it is a common phrase employed in evolution that the organism best suited to the environment survives, we should extend this statement to cover also other organisms with this capability of adaptation. Because the concept of adaptation should be discussed not from an individual but a population standpoint. It talks about not the survival of one or two organisms suited to their environment, but the survival of all with this capability of adaptation (Hasenekoğlu, 2002; Understanding Evolution, 2013). These are the organisms that could suit to any environment and are capable of passing on these capabilities to subsequent generations (Gregory, 2009).

63.25\% of the students provided wrong answers to the sixth question (Table 2). According to the supporting arguments provided by the students, majority of them wrongly believe that it is the aim of natural selection to ensure or enhance the suitability of the organism (Table 3). Indeed, natural selection does not always exhibit perfectly designed aspects. For example, the large and eye-catching tail of a bird may help to catch the attention of the female but may also draw the attention of predators around (Understanding Evolution, 2013).

$20.51 \%$ of the students provided wrong answers to the seventh question (Table 2). According to the supporting arguments provided by the students, majority of them wrongly believe that adaptation, as a common aspect of organisms, is evident in all features (Table 3). Indeed, adaptation does not lie in all features of the organisms. For instance, red color of our blood has no relevance with adaptation, it is totally associated with the chemical properties of the substance (Understanding Evolution, 2013).

7.69\% of the students provided wrong answers to the eight questions (Table 2). The supporting arguments provided by the students reveal a misconception resulting from poor understanding of the link between adaptation and natural selection (Table 3 ). The natural selection factor ensures that individuals of a population capable of suiting to their environment can successfully pass on their genes to next generations. Other factors have usually no relevance with adaptation (Hasenekoğlu, 2002).

Adaptation by natural selection is one of the most widely misunderstood scientific processes (Kelemen, Emmons, Schillaci and Ganea, 2014). In the literature, there are many studies suggesting results consistent with the findings of this research. According to the studies in the literature, students carry a myriad of misconceptions about natural selection and adaptation (Anderson, Fisher and Norman, 2002; Beardsley, Bloom and Wise, 2012; Bishop and Anderson, 1990; Clough and Wood-Robinson, 1985; Demastes, Settlage and Good, 1995; Fahrenwald, 1999; Grant, 2009; NRC, 1995; Shtulman, 2006; Shtulman and Calabi, 2012). In the literature, difficulties encountered in teaching natural selection, and common misconceptions are handled for the first time by the studies of Brumby (1979) and Lawson and Thompson (1988). Nehm and Reilly (2007) has determined that biology students have myriad of misconceptions about the mechanism of natural selection as the keystone of evolution, and studied the effects of traditional and student-oriented methods for eliminating misconceptions. In his study, Richard (2004) has revealed the misconception that organisms can acquire any essential aspect at any time during their struggle for life, and only the strong can win. In their study, Paz-y-Miño-C and Espinosa (2011) reveals the misconception that the organism deliberately suits to the environment through transformation. Weeks (2013) has found the misconception that only the best can suit, and other misconceptions about adaptation. Coley and Tanner (2012) have revealed the misconception that individual organisms adapt and change to fit their environments. Again, some other studies in literature 
reveal the misconception that organisms undergo natural selection as a need (Bishop and Anderson, 1990; Brumby, 1979; Ferrari and Chi, 1998; Boese, 2003,Kose, 2010).

\section{CONCLUSION}

Researchers have shown that students at all levels find natural selection a very challenging topic to understand (Dickes and Sengupta, 2013). Misconceptions about adaptation and natural selection that describe the process of evolution are noteworthy. Understanding the natural selection mechanism is a precondition of understanding the process of evolution, therefore conceptions about the natural selection mechanism should strictly be corrected. One of the primary reasons of the failure of correcting such misconceptions is that some pedagogic approaches pursued by teachers are not suitable for the correction of such misconceptions in students (Cunningham and Wescott, 2009). Williams (2009) argues that, since such misconceptions occur during the early period of the individual's life, it is difficult to correct them due to social pressure, and particularly due to the fact that such concepts are remote from daily life experiences. If such misconceptions are clearly explained to students without giving the opportunity to fix them throughout the educational year, such misconceptions would exactly reinstate at the end of the year (Greene 1990; Wandersee et al. 1989; Hellden and Solomon 2004; Mintzes et al. 2000).

Weeks (2013) argue that we need to find teaching methods that are much more creative than those employed in the teaching of evolution today. In some studies, it is argued that offering the evolution class throughout the whole year would create the sufficient period of time necessary to identify and cure the misconceptions (Richard, 2004). Weeks (2013) argues that much more time should be allocated to correct misconceptions and deliver an in-depth teaching of the theory of evolution, requiring the service of much more experienced teachers.

Also alternative methods can be employed in teaching evolution. For example, according to the results of a study by Spiegel et al., (2012) even a single tour to a museum themed biological evolution enhances in itself the understanding of students in evolution. Another alternative method on natural selection developed by Abraham et al. (2009) through computer-aided simulation has enhanced the learning of students. Such constructive alternative teaching methods may be an alternative to today's conventional method of teaching evolution (Weeks, 2013).

The study by a group of scientists has revealed that, in case student-centered teaching methods are employed, students' misconceptions are reduced, and evolutionary concepts used by students to explain natural selection quantitatively grow (NRC, 1998; Moore et al., 2002; Özyeral, 2008).

Browning and Hohenstein (2013) suggest that the presentation of compelling evidence, such as fossil records in the teaching of evolution may persuade children of evolution's feasibility.

As suggested by Wescott and Cunningham (2005), each teacher should have a test in hand to identify the misconceptions that may be carried by students. As reported by Wilson (2001), once the misconceptions of students are identified and explained, students' interest in the class grow. Certainly many teachers intend to identify the misconceptions carried by their students; however they do not have the time and competence necessary to develop a self-test for identifying the misconceptions. Our teachers need reliable misconception tests with construct validity that may be employed in the education. Misconceptions identified through appropriate tests should be revealed to the students, and they should be provided with the opportunity of substituting such misconceptions with true scientific facts so that their understanding of evolution is enhanced. 
If students are encouraged to use the scientific language more during the class, it is believed that students would focus on the scientific content of such concepts, leading to the reduction of misconceptions resulting from the effect of daily use (Dagher, Brickhouse, Shipman and Letts, 2004).

Given the argument of Dobzhansky (1973), "Nothing in biology makes sense except in the light of evolution", misconceptions in biology teachers require a higher level of consideration. If pre-service teachers do not gain a good understanding of the theory of evolution, it is obvious that they would not be able to effectively teach it to their students in the future. And even in case the results of such researches are introduced to the pre-service teachers to render them familiar with potential experiences in the future, they may build better learning settings for their own students.

\section{References}

Abraham, J.K., Meir, E., Perry, J., Herron, J.C., Maruca, S., and Stal, D. (2009). Addressing undergraduate student misconceptions about natural selection with an interactive simulated laboratory. Evolution: Education and Outreach, 2(3): 393-404.

Anderson, D.L., Fisher, K.M., and Norman, G.J. (2002). Development and evaluation of the conceptual inventory of natural selection. Journal of research in science teaching, 39(10), 952-978.

Atasayar, A. (2008). Kavram Öğretimi Sürecine Yönelik İ̧̧erik Geliştirme Aracının Tasarlanması Ve Kullanışlıı̆ı. Yüksek Lisans Tezi. Hacettepe Üniversitesi.

Atılboz N. G. (2004). Lise 1. Sınıf Öğrencilerinin Mitoz ve Mayoz Bölünme Konuları ile Illgili Anlama Düzeyleri ve Kavram Yanılgıları. Gazi Eğitim Fakültesi Dergisi, 24(3), 147-157.

Baker, D.R. and Piburn, M.D. (1997). Constructing Science in iddle and Secondary school classroom. Needham Heights, MA: Allyn and Bacon.

Banet, E. and Ayuso, G.E. (2003). Teaching of biological inheritance and evolution of living beings in secondary school. International Journal of Science Education, 25(3), 373-407.

Beardsley, P.M., Bloom, M.V., and Wise, S.B. (2012). Challenges and opportunities for teaching and designing effective K-12 evolution curricula. In K. S. Rosengren, S. K.

Bergman, J. (1979). Attitude of university students toward the teaching of creation and evolution in the schools. Origins, 6, 64-66.

Bishop, B. A. and Anderson, C.W. (1990). Student Conceptions of Natural Selection and its role in evolution. Journal for Research in Science Teaching, 27, 415-427.

Blackwell, W.H., Powell, M.J. and Dukes, G.H. (2003). The problem of student acceptance of evolution. Journal of BiologicalEducation, 37(2), 58-67.

Boese, W.J. (2003) Natural Selection in Flaagan K.J. and Pelaez, N.J. Excellence in Life Science. Dubuque, IA: Kendall/Hunt.

Browning, E., and Hohenstein, J. (2013). The use of narrative to promote primary school children's understanding of evolution. Education 3-13, 43(5), 530-547.

Brumby, B. (1979). Problems in learning the concept of natural selection. Journal of Biological Education, 13(2), 119-122.

Clough, E.E., and Wood-Robinson, C. (1985). How secondary students interpret instances of biological adaptation. Journal of Biological Education, 19, 304-310.

Coley, J.D., and Tanner, K.D. (2012). Common origins of diverse misconceptions: cognitive principles and the development of biology thinking. CBE-Life Sciences Education, 11(3), 209-215.

Creswell, J.W. (2008). Educational research planning, conducting and evaluating quantitative and qualitative research. International Pearson Merril Prentice Hall.

Cunningham, D.L., and Wescott, D.J. (2009). Still more "fancy" and "myth" than "fact" in students' conceptions of evolution. Evolution: Education and Outreach, 2(3), 505-517.

Dagher Z.R. and BouJaoude S. (2005), Students' perceptions of the nature of evolutionary theory. Science Education, 89, 378-391.

Dagher, Z.R., Brickhouse, N.W., Shipman, H., and Letts, W.J. (2004). How some college students represent their understandings of the nature of scientific theories. International Journal of Science Education, 26(6), 735-755.

Demastes, S.S., Settlage, J. and Good, R. (1995). Students' conception of natural selection and its role in evolution: Cases of replication and comparison. Journal of Research in Science Teaching, 32, 535550. 
Dickes, A.C., and Sengupta, P. (2013). Learning natural selection in 4th grade with multi-agent-based computational models. Research in Science Education, 43(3), 921-953.

Dobzhansky, T. (1973). Nothing in biology makes sense except in the light of evolution. The American Biology Teachers, 35, 125-129.

Driscoll, D. L., Appiah-Yeboah, A., Salib, P., \& Rupert, D. J. (2007). Merging qualitative and quantitative data in mixed methods research: How to and why not. Ecological and Environmental Anthropology (University of Georgia), 18.

Fahrenwald, C.R. (1999). Biology teachers' acceptance and understanding of evolution and the nature of science. Doctoral Thesis. University of South Dakota.

Ferrari, M., and Chi, M.T. (1998). The nature of naive explanations of natural selection. International Journal of Science Education, 20(10), 1231-1256.

Gould, S.J. (1982). Darwinism and the Expansion of Evolutionary Theory. Science, 216, 380-387.

Gould, S.J. (2002). The structure of evolutionary theory. Cambridge: Harvard University Press.

Grace, J.K. (2011). Impact of a targeted lab and lab instructor intervention on student understanding of evolution in a major's general biology. Doctoral Thesis. California State University.

Grant, B.W. (2009). Practitioner research improved my students' understanding of evolution by natural selection in an introductory biology course. Teaching Issues and Experiments in Ecology, 6(Research \#4).

Greene, E.D. (1990). The logic of university students' misunderstanding of natural selection. Journal of Research in Science Teaching, 27(9), 875-885.

Gregory, T.R. (2009). Understanding natural selection: Essential concepts and common misconceptions. Evolution: Education and Outreach, 2, 156-175.

Hasenekoğlu, ì. (2002). Evrim. Atatürk Üniversitesi Kazım Karabekir Eğitim Fakültesi.

Helldén, G.F., and Solomon, J. (2004). The persistence of personal and social themes in context: Long-and short-term studies of students' scientific ideas. Science Education, 88(6), 885-900.

Kelemen, D., Emmons, N.A., Schillaci, R.S., and Ganea, P.A. (2014). Young children can be taught basic natural selection using a picture-storybook intervention. Psychological science, 25(4), 893-902.

Köse, Ö.E. (2010). Biology students' and teachers' religious beliefs and attitudes towards theory of evolution. Hacettepe Üniversitesi Eğitim Fakültesi Dergisi, 1, 189-200.

Lawson, A.E., and Thompson, L.D. (1988). Formal reasoning ability and misconceptions concerning genetics and natural selection. Journal of Research in Science Teaching, 25, 733-746.

Mann, M., and Treagust, D.F. (1998). A Pencil and Paper Instrument to Diagnose Students' Conception of Breathing, Gas Exchange and Respiration. Australian Science Teachers Journal, 44(2), 55-59.

Meir, E., Perry, J., Herron, J.C. and Kingsolver, J. (2007). College students' misconceptions about evolutionary trees. American Biology Teacher, 69, 71-76.

Miller, J.D., Scott E.C. and Okamoto, S. (2006). Public acceptance of evolution. Science, 313, 765-766.

Miller, KR. (1999). Finding Darwin's God: A scientist's search for common ground between God and evolution. New York: Harper Collins.

Mintzes, J.L., Wandersee, J.H., and Novak, J.D.(Eds.) (2000). Assessing science understanding: A human constructivist view (pp. 198-223). San Diego: Academic Press.

Moore, J.A. (2002). From Genesis to genetics: The case of evolution and creationism. Los Angeles: University of California Press.

Moore, R., Mitchell, G., Bally, R., Inglis, M., Day, J. and Jacops, D. (2002). Undergraduates' Understanding of Evolution: Ascriptions of agency as a problem for student learning. Journal of Biological Education, 36(2), 65-71.

National Research Council (NRC). (1995). National Science Education Standards. Washington D.C.: National Academy Press.

National Research Council (NRC). (1998). National science education standards. Washington, DC: National Academy Press.

Nehm, R.H. and Reilly, L. (2007). Biology majors' knowledge and misconceptions of natural selection. BioScience, 57(3), 263-272.

Özyeral-Bakanay, Ç.D. (2008). Biyoloji Öğretmen Adaylarının Evrim Teorisine Yaklaşımları ve Bilimin Doğasına Bakış Açıları. Yüksek Lisans Tezi, Marmara Üniversitesi. 
Paz-y-Miño-C G. and Espinosa, A. (2011). New England faculty and college students differ in their views about evolution, creationism, intelligent design, and religiosity. Evolution: Education and Outreach, 2, 323-42.

Pazza, R., Penteado, P.R. and Kavalco, K.F. (2010). Misconceptions about evolution in Brazilian freshmen students. Evolution: Education and Outreach, 3(1), 107-113.

Richard, S.M. (2004). Use of concept mapping to clarify misconceptions about natural selection in an allmale high school biology classroom. Doctoral Thesis. California State University.

Rutledge, M.L. and Warden, M.A. (1999). The development and validation of the Measure of Acceptance of the Theory of Evolution instrument. School Science \& Mathematics, 99, 13-18.

Selvi, M. and Yağbasan, R. (2004). Basit Sarkaç Sisteminde Mekanik Enerjinin Korunumu Konusunda Öğrencilerin Kavram Yanılgıları. Gazi Eğitim Fakültesi Dergisi, 24(3), 23-38.

Shtulman, A. (2006). Qualitative differences between naïve and scientific theories of evolution. Cognitive Psychology, 52, 17-194.

Shtulman, A., and Calabi, P. (2012). Cognitive constraints on the understanding and acceptance of evolution. In K. S. Rosengren, S. K. Brem, E. M. Evans, and G. M

Spiegel, A.N., Evans, E.M., Frazier, B., Hazel, A., Tare, M., Gram, W., and Diamond, J. (2012). Changing museum visitors' conceptions of evolution. Evolution: Education and Outreach, 5(1), 43-61.

Understanding Evolution (2013). A collaborative project of the University of California Museum of Paleontology and the National Center for Science Education. Access Date: 16.10.2013 Web Page URL: http://evolution.berkeley.edu/evolibrary/misconceptions_faq.php.

Van Dijk, E.M. (2009). Teachers" views on understanding evolutionary theory: A PCK study in the framework of the ERTE-model. Teaching and Teacher Education, 25, 259-267.

Van Dijk, E.M. and Kattmann, U. (2009) Teaching evolution with historical narratives. Evolution, Education and Outreach, 2, 479-489.

Varela, R.G. (2009). Evolution Misconceptions in Roman Catholic High School Students: A Comparative Study. Master Thesis. California State University.

Voska, K.W., and Heikkinen, H.W. (2000). Identification and Analysis of Student Conception Used to Solve Chemical Equilibrium Problems. Journal of Research in Science Teaching, 37(2), 160-176.

Wandersee, J.H., Mintzes, J.J., and Arnaudin, M.W. (1989). Biology from the learner's viewpoint: A content analysis of the research literature. School Science and Mathematics, 89(8), 654-668.

Weeks, B.E. (2013). Unweaving misconceptions: Guided learning, simulations, and misconceptions in learning principles of natural selection. Doctoral Thesis. Capella University.

Wescott, D.J., and Cunningham, D.L. (2005). Recognizing student misconceptions about science and evolution. Age, 22(92), 23-29.

Williams, J.D. (2009). Belief versus acceptance: Why do people not believe in evolution?. BioEssays, 31(11), 1255-1262.

Wilson, J.A. (2001). Psuedoscientific Beliefs among College Students. Reports of the National Center for Science Education, 21, 9-13.

Woods, C.S. and Scharmann, L.C. (2001). High School Students' Perceptions of Evolutionary Theory. Alıntı Tarihi: 16.10.2013 Web Page URL: http://www.indiana.edu/ ensiweb/pap.hsev.pdf. Access Date: 11 Nisan 2013.

Yağbasan, R. and Gülçiçek, Ç. (2003). Fen Öğretiminde Kavram Yanılgılarının Karakteristiklerinin Tanımlanması. Pamukkale Üniversitesi Eğitim Fakültesi Dergisi, 13, 102-120.

Yates, T.B. (2011). Student Acquisition Of Biological Evolution-Related Misconceptions: The Role Of Public High School Introductory Biology Teachers. Doctoral Thesis. University Of Oklahoma. 